\title{
EXPERIMENTAL INVESTIGATION OF THE EFFECT OF PHARMACEUTICAL COMPOSITION ON THE CENTRAL NERVOUS SYSTEM
}

\author{
Syrova G., Lukianova L., Sinelnik V., Krasnikova Yu., Salam Logina \\ Kharkiv National Medical University, Ukraine \\ https://doi.org/10.35339/ic.6.3.162-167
}

\begin{abstract}
It is known that combination of non-steroidal anti-inflammatory drugs with other drugs can cause complementary effects, or potentiate the effects of each other. Object and methods. The objective of this experiment is to analyze the use of a new pharmaceutical composition consisting of nonsteroidal anti-inflammatory drug of the coxib group (rofecoxib) and an immunomodulator of lycopid (glucosaminylmuramyl dipeptide). An experiment on laboratory animals was conducted in order to view the effect of rofecoxib, licopid and their pharmacological composition on the central nervous system and on emotional-behavioral reactions in an "open field" test under formalin edema conditions. Results Previously, we studied the pharmaceutical compositions of nonsteroidal anti-inflammatory drugs of different chemical structure with the psychostimulant caffeine. The results indicated that caffeine potentiated the pharmacological effects of nonsteroidal anti-inflammatory drugs. In this study, we set a goal to create a pharmaceutical composition of rofecoxib with licopid and investigated its effect on the emotional-behavioral reactions of rats under formalin edema conditions. Ànalysis of the experimental results show that the addition of licopid to rofecoxib contributed to an increase in rat's locomotor and orienting-research activities and also an increase in the indicators of their emotional reactions (urination and defecation) compared to the mono-administration of rofecoxib. Conclusions. The pharmaceutical composition of rofecoxib and licopid is expedient and promising for the study of anti-inflammatory and analgesic effects.
\end{abstract}

Keywords: "open field", licopid, rofecoxib, pharmaceutical composition, formalin edema.

\section{Introduction}

The inflammatory process in the human body leads to a disruption of many systems in the body, including immune, endocrine and nervous systems. It is often accompanied by severe pain, edema, spasms, etc. [1, 2]. Therefore, an urgent problem of the pharmaceutical development is the search for new effective compositions containing known non-steroidal, anti-inflammatory drugs (NSAIDs), whose pharmacological effects are achieved through rational choice of chemicals.

Corresponding Author:

Larysa Lukianova Vladimirovna, Ph.D.,

Assistant Professor, Department of Medical

and Bioorganic Chemistry.Kharkiv National

Medical University, Ukraine.

E-mail:larluk2013@gmail.com
The benefit of combining drugs in comparison to monotherapy is that they can effectively eliminate pain and inflammation, rather than administering each component individually [3]. Such combinations enable the addition of active substances in drugs using lower doses, which reduces toxicity and, thus, the negative side effects [3, 4].

It is known that NSAIDs are often combined with other drugs that may cause complementary effects, or potentiate the effects of each other [5-7]. The fact that there are no combined rofecoxib based medicines is the reason we have selected coxib as our study object (namely, rofecoxib).

Rofecoxib-([4-[4-(Methylsulfonyl)phenyl]-3phenyl-2(5H)-furanone]) NSAIDs- is a synthetic preparation of the coxib group and it contains a sulfone side chain in its structure: 


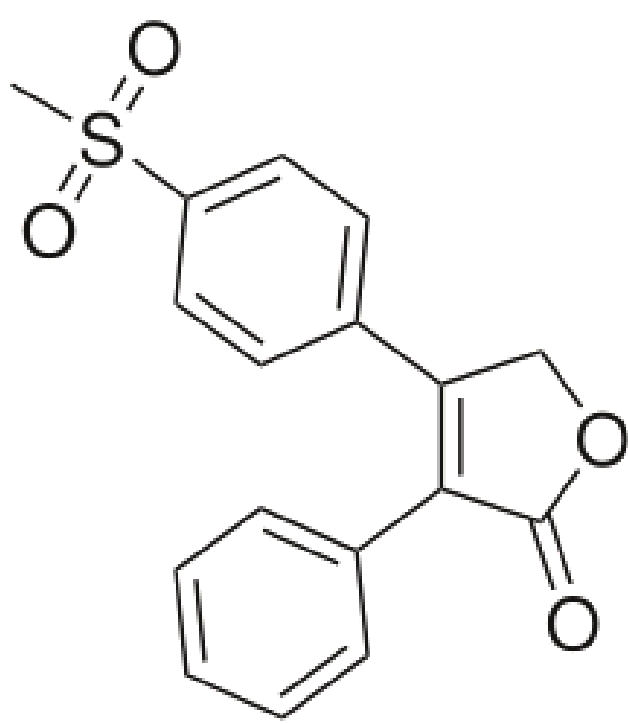

Fig. 1. Rofecoxib (rofecoxibum, 4-(4-methylsulfonylphenyl)-

3-phenyl-5H-furan-2-one) C17H14O4S

Rofecoxib is a highly selective inhibitor of cyclooxygenase-2 isoform (COX-2), which is formed exclusively at inflammatory sites and provides the conversion of arachidonic acid to prostaglandin (PG). COX-2 participates in the formation of inflammatory mediators: PG, prostacyclin and thromboxane. The activity of rofecoxib, as well as other preparations of the group of coxibs, isoform COX-2, is due to the peculiarity of their active center structures of COX-2 and the molecule of coxibs. In the molecules of coxibs, there is a rigid side chain, which allows these drugs to penetrate into the cavity of the COX-2 molecule, and interact precisely with this isoform COG [8]. Rofecoxib has a pronounced analgesic and anti-inflammatory effect, compared with other NSAIDs, it has a chondroprotective effect, which reduces the concentration of PG in the cerebrospinal fluid, leading to the suppression of secondary hyperalgesia development, therefore, allowing the drug to be used for trauma and postoperative pain syndrome [9].

The second component of the potential analgesic drug is the immunomodulator, licopid (Glucoseminylmuramildipeptidum(GMDP), [4-O(2-Acetylamino-2-deoxy-beta-D-glucopyranosyl)$\mathrm{N}$-acetylmuramyl]-L-alanyl-D- $\alpha$-glutamylamide, $\mathrm{C}_{25} \mathrm{H}_{43} \mathrm{~N}_{5} \mathrm{O}_{15}$ ), which belongs to the group of cytokines and immunostimulants [10]. The mechanism of its action resembles the process of natural immunoregulation [11, 12]. Licopid exhibits antibacterial and antiviral activity and exerts leukopoietic effect. Licopid is a synthetic
GMDP free from bacterial impurities. Licopid stimulates all parts of the immune system, but primarily activates phagocytosis, that is, the ability of cells to absorb foreign cells, bacteria and mushrooms. In addition, it activates macrophages to begin synthesizing immune mediators, cytokines, that enhances the ability of lymphocytes to kill foreign cells, to produce protective antibodies and to increase the formation of new leukocytes involved in phagocytosis. Licopid is a highly effective and safe immunotropic drug; it is convenient to use, and it can be tolerated [8, 12].

\section{Purposes, subjects and methods:}

2. Purposes, subjects and methods:

2.1. Purpose - to search, create and study a new pharmaceutical composition containing NSAIDs from the group of coxib (rofecoxib) and licopid by influencing the central nervous system (CNS) and emotional-behavioral reactions (EBR) in an experiment on laboratory animals in an "open field" test.

\subsection{Subjects \& Methods}

Experimental justification for the use of a new pharmaceutical composition consisting NSAIDs of the coxib group (rofecoxib) and licopid.

Experimental studies of pharmacological activity were carried out on laboratory animals (36 white WAG rats weighing 180-280 g of both sexes) at the Department of Medical and Bioorganic Chemistry of Kharkiv National Medical University. The research was conducted in accordance with the methodological recommendations of the State Pharmacological Center of the Ministry of Health of Ukraine [13]. Recount from human doses to rats was carried out using a coefficient of species sensitivity according to Yu.R. Rybolovlev [14]. When choosing the number of animals and their distribution in groups, the economical approach, bioethical rules and statistical requirements were taken into account.

The study was carried out on laboratory animals from the experimental biological clinic of KhNMU taking into account the norms of storage, care and feeding (air temperature - 23$25^{\circ} \tilde{\mathrm{N}}$, lighting - in the room $100 \mathrm{~lx}$, in the cell 20-40 lx) [15 ] Length of stay of laboratory animals - 1.5 months; period of acclimatization 2 weeks; main ration - vegetables, fodder beets; water source - tap water. The rats were kept in vivarium in accordance with the rules of humane treatment of laboratory animals. The studies were conducted in compliance with the principles of the "European Convention for the Protection of Vertebrate Animals used for Experimental and 
Scientific Purposes" (Strasbourg, 1986) [16], Directive 2010/63 / EU of the European Parliament and of the Council of the European Union "On the Protection of Animals Used for Scientific Purposes" "(Brussels, 2010) [17] and" General Ethical Principles of Experiments on Animals "(Kyiv, 2001), the Decree of the First National Congress on Bioethics (Kyiv, 2009) [18]. Experiments were conducted in the first half of the day, which according to the literature agrees with the dependence of the main pharmacological parameters and pharmacological activity of the drugs taken from the circadian rhythms [19, 20].

Statistical processing of the data was carried out using generally accepted methods of statistical analysis (mean, average error, probability criterion of Fisher-Stuent) using MS Excel and Stat Graphics Plus 2.1 programs [21].

Studies of the effect of rofecoxib, licopid and their pharmaceutical composition on rat's EBR were also conducted under formalin edema conditions. The rats were divided into 6 groups of 6 animals each. Animals of the $1^{\text {st }}$ intact group intragastrically received single dose of 3\% starch mucus ( $2 \mathrm{ml}$ per $200 \mathrm{~g}$ of rat's weight). Animals of the $2^{\text {nd }}$ group received $3 \%$ starch mucus and the formalin induced edema was modeled by subplanar administration $0.1 \mathrm{ml}$ of $2 \%$ formalin solution into hind paw of rat [13]. Animals from experimental groups 3-6 were intragastrically administered studied drugs in the form of a suspension of $3 \%$ starch mucus: animals of the $3^{\text {rd }}$ group - rofecoxib in the dose of $1.3 \mathrm{mg}$ per $1 \mathrm{~kg}$ of rat's weight), $4^{\text {th }}-$ licopid $(0.6 \mathrm{mg} / \mathrm{kg})$, $5^{\text {th }}$ group received composition of rofecoxib $(1.3 \mathrm{mg} / \mathrm{kg})$ with licopid $(0.6 \mathrm{mg} / \mathrm{kg}), 6^{\text {th }}$ group reference drug sodium diclofenac $(8 \mathrm{mg} / \mathrm{kg})$. Maximum development of formalin induced edema is observed 4 hours after its modeling [13]. $3 \%$ starch mucus, drugs and their pharmaceutical composition were administered 1 hour before, taking into account their pharmacokinetic and pharmacodynamic characteristics.

Interaction of animal and the environment is based on mechanisms of nervous, humoral and immune regulation. Depending on the genetically determined characteristics of these processes, animals react differently to environmental changes. This allows them to distinguish different individual-typological properties. In addition, individual peculiarities of animals are determined by the general condition of the animal at the time of exposure to extreme conditions, a preliminary study of the decision of a stressful situation and other features acquired during life.
While studying the mechanisms of pharmaceutical action of drugs, it is important to study their effect on characteristics of animal behavior. Absence of verbal contact limits number of possible tests. The most popular and informative is an "open field" test [22, 23].

Evaluations of the influence of the drugs and their composition on the characteristics of animal's behavior was carried out by comparing groups 3-5 with the control group (group 1), and with formalin edema (group 2) and with reference drug diclofenac sodium (group 6). Observation of the parameters of the approximate research activity of the rats in the "open field" test [22, 23] and the multi-parameter method for evaluating anxietyphobic states according to the generally accepted method was carried out within 3 minutes [24].

The parameter of the orienting-research activity of the rats in "open field" test is characterized by a number of variables: the number of crossed squares (locomotor activity), vertical racks and surveyed openings (routine-research activity), washings (grooming), ovaries and boluses (emotional reactions) according to the generally accepted the method [23, 24].

\section{Conflict of interests}

The authors declare that they have no competing interests.

\section{Results and discussion}

The influence of the drugs under study and their composition on rat's locomotor activity (number of crossed squares). Formalin induced edema (group 2) reduced the rat's locomotor activity in 1.9 times relative to the control group (Table).

The mono-administration of rofecoxib (group 3) and licopid (group 4) was not significantly different statistically from the rats' locomotor activity of that of group 2, the findings are significantly different statistically from the control values (group 1). The composition of rofecoxib with licopid increased the rat's locomotor activity relative to groups $2-4$, which did not significantly differ statistically from the reference drug (group 6), that is, there was a normal locomotor activity (see Table).

An analysis of the rat's orienting-research activities in "open field" test, in terms of the number of sets and explored holes, reveals the motivational component of the animal's characteristics. In this case, they try to enter into indirect contact with objects located at a distance: the rats sniffed to objects located outside the "open field".

The number of crossed squares. Formalin induced edema (group 2) contributed to 
Indices of the rats' behavioral activity and emotional reactions under formalin edema according to "open field" method

\begin{tabular}{|c|c|c|c|c|c|c|c|}
\hline \multirow[b]{2}{*}{ № } & \multirow{2}{*}{$\begin{array}{l}\text { Groups } \\
\text { of rats }\end{array}$} & \multirow{2}{*}{$\begin{array}{c}\text { Locomotor } \\
\text { activity } \\
\text { number } \\
\text { of crossed } \\
\text { squares }\end{array}$} & \multicolumn{2}{|c|}{$\begin{array}{c}\text { Orientation-research } \\
\text { activity }\end{array}$} & \multicolumn{3}{|c|}{$\begin{array}{l}\text { Emotional } \\
\text { reactions }\end{array}$} \\
\hline & & & $\begin{array}{l}\text { number } \\
\text { of sets }\end{array}$ & $\begin{array}{c}\text { number } \\
\text { of explored } \\
\text { holes }\end{array}$ & $\begin{array}{c}\text { number } \\
\text { of washing } \\
\text { (grooming) }\end{array}$ & $\begin{array}{c}\text { number } \\
\text { of urinations }\end{array}$ & $\begin{array}{c}\text { number } \\
\text { of defecations }\end{array}$ \\
\hline 1. & $\begin{array}{l}\text { Control } \\
(\mathrm{n}=6)\end{array}$ & $18.50 \pm 0.62$ & $4.83 \pm 0.65^{* *}$ & $7.17 \pm 1.01$ & $8.50 \pm 2.99$ & $1.17 \pm 0.31$ & $4.17 \pm 0.48$ \\
\hline 2. & $\begin{array}{l}\text { Formalin-induced } \\
\text { edema }(n=6)\end{array}$ & $10.00 \pm 0.52$ & $2.17 \pm 0.79$ & $2.17 \pm 0.65$ & $1.67 \pm 1.05$ & $1.00 \pm 0.00$ & $2.67 \pm 0.42$ \\
\hline 3. & $\begin{array}{l}\text { Rofecoxib } \\
(n=6)\end{array}$ & $10.25 \pm 0.63$ & $3,50 \pm 0,87$ & $1.00 \pm 0.41$ & $0.67 \pm 0.67$ & $1.00 \pm 0.48$ & $2.75 \pm 0.48$ \\
\hline 4. & $\begin{array}{l}\text { Licopid } \\
(n=6)\end{array}$ & 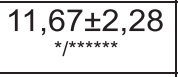 & $2.67 \pm 0.62$ & $2.17 \pm 0.48$ & $1.50 \pm 0.96$ & $1.17 \pm 0.17$ & $2.83 \pm 0.95$ \\
\hline 5. & $\begin{array}{l}\text { Rofecoxib + } \\
\text { licopid }(n=6)\end{array}$ & $18.50 \pm 1.20$ & 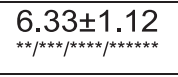 & $3.83 \pm 0.87$ & $0.83 \pm 0.40$ & $1.50 \pm 0.22$ & $2.83 \pm 0.87$ \\
\hline 6. & $\begin{array}{l}\text { Sodium } \\
\text { diclofenac }(n=6)\end{array}$ & $18.00 \pm 0.82$ & $6.25 \pm 0.25$ & $6.50 \pm 0.65$ & $5.75 \pm 2.10$ & $1.50 \pm 0.29$ & $2.50 \pm 0.87$ \\
\hline
\end{tabular}

Notes (mean \pm error in mean).

$\mathrm{n}$ - number of rats in each group;

* - the difference is significant as compared to the control group, $\mathrm{p}<0.05$;

$* *$ - the difference is significant as compared to formalin-induced edema, $\mathrm{p}<0.05$;

*** - the difference is significant as compared to the mono-administration of rofecoxib, $\mathrm{p}<0.05$;

$* * * *$ - the difference is significant as compared to the mono-administration of licopid, $\mathrm{p}<0.05$;

$* * * * *$ - the difference is significant as compared to the administration of the rofecoxib and licopid composition, $\mathrm{p}<0.05$;

$* * * * * *$ - the difference is significant as compared to the mono-administration of sodium diclofenac, $\mathrm{p}<0.05$.

statistically significant reduction in the number of sets to group 2 (see Table). The monoadministration of rofecoxib (group 3) there was an increase in the number of racks by 1.6 times relative to group 2, which did not significantly differ statistically from the values of both control and reference drug. The mono-administration of licopid (group 4) increased the number of sets by 1.2 times compared with group 2 , and the findings were also significantly statistically different from the control values (group 1) and the reference drug (group 6). Composition of rofecoxib and licopid showed a statistically significant increase in the number of explored holes relative to the experimental groups 2-6 and remained at the level of animals in group 6 (reference drug) (see Table).

The number of explored holes. A variety of rat's orienting-research activities is the number of examined openings - an indicator of the renal reflex, which indicates the ability of the animal to explore the "open field", in particular, to look into the openings. The number of examined openings characterizes cognitive activity of rats.

Formalin induced edema (group 2) contributed to statistically significant reduction in the number of examined openings by 3.3 times in comparison with the control group. The mono-administration of rofecoxib (group 3) has contributed to a decrease in the number of examined holes in rats relative to groups 1 and 2 . The monoadministration of licopid did not affect the number of explored holes in the conditions of formalin edema. Introduction of the pharmaceutical composition of rofecoxib with lycopid (group 5) increased the cognitive activity of rats in 1.8 times relative to group 2 , in 3.8 times relative to group 3 (mono-administration of rofecoxib). These indications did not significantly differ statistically from the control group and the index of the reference drug, that is, the introduction of this composition contributed to the normalization of vertical activity (see Table).

Emotional reactions in rats are an important characteristic of animal behavior in the "open field". The level of emotional state of rats is estimated by the number of washings (grooming), ovaries and boluses (defecations).

Cosmetic behavior of rats (grooming). Traditionally, rats devote most of their time to scrubbing their body, as compared with moving in space. Grooming closely correlates with motor activity. Therefore, in the study of medicinal products, this behavioral characteristic is particularly interesting.

Formalin induced edema shows that there was a decrease in the amount of washings by 5.1 times relative to control (group 1). The monoadministration of rofecoxib, licopid and their 
pharmaceutical composition did not positively affect grooming in the conditions of formalin edema (see Table).

Diuresis and defecation. The level of the rat's emotional state is measured by observing the urination and defecation number. The rate of the rat's emotional stress is evaluated by these numbers.

Formalin induced edema (group 2) contributed to the reduction of urinations and defecation, in 1.2 times and 1.6 times respectively, relative to the control. The mono-administration of rofecoxib, licopid at the formalin-induced edema did not affect the number of urinations and defecations. Introduction of the composition of rofecoxib and licopid contributed to the increase in diuresis and the number of defecations movements relative to group 2 (correspondingly), which was not significantly, statistically different from the reference drug (see Table).

Previously, at the Department of Medical and Bioorganic Chemistry of Kharkiv National Medical University (KhNMU) we studied the pharmaceutical compositions of NSAIDs of different chemical structure (N-(4-hydroxyphenyl) acetamide, 4-hydroxy-2-methyl-N-2-pyridinyl2H-1,2-benzothiazine-3-carboxamide-1,1-dioxide, [o-(2,6-dichloro-aniline)-phenyl] acetic acid sodium salt, 4-hydroxy-2-methyl-N-(5-methyl-2thiazolyl)-2H-1,2-benzothiazin-3-carboxamide1,1-dioxide) with the psychostimulant caffeine (1,3,7-trimethylxanthine) [2-6]. The results indicated that caffeine potentiated the pharmacological effects of NSAIDs of different chemical structure. In this study, we set a goal to create a pharmaceutical composition of the
NSAIDs group of coxib (rofecoxib) with a new adjuvant licopid and investigated its effect on the EBR of rats under the conditions of formalin edema, which has not been experimentally tested previously.

Earlier, employees of D.O.Alpern Department of Pathological Physiology of KhNMU studied $l^{3}$ copid in an animal experiment: the possibility of its influence on the leukocyte reaction of peripheral blood in case of carrageenan secondary chronic inflammation was evaluated $[25,26]$; studied the effect of $l^{3}$ copid on the central link of the blood system, i.e. bone marrow hematopoiesis [27]. The results of these studies show that the use of glucosaminylmuramyl dipeptide leads to a decrease in the chronization of the process, which shows the advisability of using it to prevent chronic inflammation. The authors consider promising future studies related to the improvement of pathogenetic therapy, as well as the prevention of chronic inflammation.

\section{Conclusions}

A study was conducted to evaluate the effect of rofecoxib and licopid and their pharmaceutical composition on EBR indices in rats by the "open field" method under the conditions of formalin edema, which showed that the introduction of the pharmaceutical composition of rofecoxib and licopid contributed to an increase in rat's locomotor and orientation-research activity, in its indicators of emotional reactions (diuresis and defecations) compared with the monoadministration of rofecoxib.

The pharmaceutical composition of rofecoxib and lycopodis is expedient and promising for the study of anti-inflammatory and analgesic effects.

\section{References}

1. B³lousov, Ju.B., Moiseev, V.S. (1997). Klinicheskaja farmakologija i farmakoterapija: Rukovodstvo dlja vrachej [Clinical Pharmacology and Pharmacotherapy: A Guide for Doctors]. M.: Universum Pablishing.

2. Syrovaya, A.O., Grabovetskaya, E.R. (2015). Experimental study of caffeine influence on antiexudative activity of known NSAIDs of different chemical structure. European Applied Sciences, 9, 5-7.

3. Syrovaya, A.O., Grabovetskaya, E.R. (2016). Experimental substantiation for new medicinal compositions design. European Applied Sciences, 1, 6-9.

4. Savelieva, E.V., Levashova, O. L., Masih, T. (2016). Effects of caffeine, acetaminophen, carbamazepine and their compositions on lipid peroxidation and state of the antioxidant system in a blood serum of rats: Actual Problems Of Clinical And Theoretical Medicine. Àbstract Book î f IXth International Interdisciplinary Scientific Conference of Young Scientists ànd Medical Students ( ${ }^{2}$ nternational Scientific ${ }^{2}$ nderdisciplinary Ñongrence - ISIC), Kharkiv, 53-54.

5. Boiko, I., Syrova, G., Ermolenko, T. (2010). Experimental conformation of the caffeine's potentiation of the analgetic properties. 3th International Scientific Interdisciplinary Congress of medical students and young doctors. Kharkiv, 14.

6. Syrovaya, A.O., Bachinskiy, R.O., Grabovetskaya, E.R. (2014). Creation of new drug compositions and pharmacological substantiation of their suitability for pain syndromes and inflammations in experimental rats. Inter colleqas, 1, 13-24.

7. Offermanns, S. (2008). Encyclopedia of Molecular Pharmacology. In: Offermanns, S., Rosenthal, W., $2^{\text {nd }}$ ed., Berlin, Heidelberg, New York: Springer-Verlag. 
8. Mashkovskij, M.D. (2012). Lekarstvennye sredstva [Medicines]. Moskva: Novaja Volna.

9. Vogel, H. (2007). Drug discovery and evaluation: pharmacological assays. Springer Science and Business Media.

10. Nesmejanov, V.A. (1997). Mehanizm dejstvija i klinicheskaja jeffektivnost' immunomoduljatora gljukozaminilmuramil dipeptida (likopida) [The mechanism of action and clinical efficacy of the immunomodulator glucosaminylmuramyl dipeptide (licopid)]. Klinicheskaja medicina, 75, 3, 11-15.

11. Nesmejanov, V.A. (1998). Gljukozaminilmuramoilpeptidy: na puti k ponimaniju molekuljarnogo mehanizma biologicheskoj aktivnosti [Glucosaminylmuramoyl peptides: Towards an Understanding of the Molecular Mechanism of Biological Activity]. International Journal of Immunorehabilitation, 10, 19-29.

12. Ivanov, V.T., Haitov, R.M., Andronova, T.M., Pinegin B.V. (1996) Likopid (gljukozaminilmuramildipeptid) - novyj otechestvennyj vysokojeffektivnyj immunomoduljator dlja lechenija i profilaktiki zabolevanij, svjazannyh so vtorichnoj immunnologicheskoj nedostatochnost'ju [Licopid (glucosaminylmuramyl dipeptide) - a new domestic highly effective immunomodulator for the treatment and prevention of diseases associated with secondary immunological insufficiency]. Immunologija, 2, 4-6.

13. Dokl ${ }^{3} n^{3} \mathrm{chn}^{3}$ dosl $^{3} \mathrm{dzhennja}$ l $^{3} \mathrm{kars}^{\prime} \mathrm{kih}$ zasob $^{3} \mathrm{v}$ : metodichn ${ }^{3}$ rekomendac ${ }^{3} \dot{\mathrm{c}}$ [Preclinical research of medicinal products: methodical recommendations]. (2001). Za red. O. V. Stefanova. Ki ¿v.

14. Rybolovlev, Ju.R., Rybolovlev, R.S. (1979). Dozirovanie veshhestv dlja mlekopitajushhih po konstantam biologicheskoj aktivnosti [Dosing of substances for mammals according to the constants of biological activity]. Doklady AN SSSR, 6, 1513-1516.

15.Deason, R.M. (2006). Housing, Husbandry and Handling of Rodents for Behavioral Experiments. Nature Protocols, 1, 2, 936-946.

16. European convention for the protection of vertebrate animals used for experimental and other scientific purposes (1986). Council of European. Strasbourg, ${ }^{1}$ 123. 51 p.

17. Directive (EU) 2010/63/EU of the European Parliament and of the Council of 22 September 2010 On the Protection of Animals Used for Scientific Purposes. Official Journal of the European Union (2010), 276, 33-79.

18.Suchasn ${ }^{3}$ problemi b ${ }^{3}$ oetiki [Modern problems bioetiki] (2009). V ${ }^{3} \mathrm{dpov}^{3}$ dal'nij redaktor Kund ${ }^{30} \mathrm{~V}$, Ju. ${ }^{2}$ Ki ¿̇v: Akademper ${ }^{3}$ odika.

19. Drogovoz, S.M. i drugie (2016). Hronofarmakologija dlja vracha, provizora i studenta: uchebnikspravochnik [Chronopharmacology for the doctor, pharmacist and student: a tutorial guide]. Pod redakciej prof. Drogovoz S.M. Har'kov: Titul.

20. Manual of Stroke Models in Rats (2009). In.: Yanling Wang-Fisher, Ed., London, New York: CRC Press.

21. Glanc, S. (1999). Mediko-biologicheskaja statistika [Biomedical statistics]. Pod redakciej Buzikashvili N.E., Samojlova D.V., per. s angl. Moskva: Praktika.

22. Jackson, H.F., Broadhurst, P.L. (1982). The effects of parachlorophenylalanine and stimulus intensity on open-field test measures in rats. Neuropharmacology, 21, 1279-1282.

23. Hall, C.S. (1936). Emotional behavior in the rat. III. The relationship between emotionality and ambulatory activity. J. comp. physiol. Psychol, 22, 345-352.

24.Buresh, Ja., Bureshova, O.P., H'juston, Dzh. (1991). Metodiki i osnovnye jeksperimenty po izucheniju mozga i povedenija [Methods and main experiments on the study of the brain and behavior]. Pod red. Batueva A.S. Moskva.

25.Shevchenko A. N., Bibichenko V. A. (2016). Vyrazhennost' lejkocitarnoj reakcii perifericheskoj krovi pri karageninovom vtorichno hronicheskom vospalenii na fone primenenija gljukozaminilmuramildipeptida [The severity of the peripheral blood leukocyte reaction with carrageenan secondary chronic inflammation with glucosaminylmuramyl dipeptide]. Eksperimental'na ${ }^{3} \mathrm{kl}^{3} \mathrm{n}^{3} \mathrm{chna}$ medicina, 2 (71), 221-227.

26. Shevchenko A. N., Bibichenko V. A. (2017). Izuchenie dinamiki lejkocitarnoj reakcii krovi pri karaginenovom hronicheskom vospalenii na fone ispol'zovanija gljukozaminilmuramildipeptida [The study of the dynamics of the blood leukocyte reaction in chronic carrageenan inflammation with the use of glucosaminyl muramyl dipeptide]. Dosjagnennja ta perspektivi eksperimental'no $\dot{\mathrm{c}}^{3} \mathrm{kl}^{3} \mathrm{n}^{3} \mathrm{chno}_{\mathrm{c}} \operatorname{endokrinolog}^{3} \dot{\mathrm{c}}$

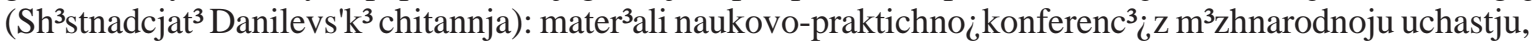
Hark $^{3}$ v, 116-117.

27. Shevchenko A. N., Bibichenko V. A. (2016). Osobennosti kostno-mozgovogo krovetvorenija pri vtorichno hronicheskom vospalenii na fone primenenija gljukozaminilmuramildipeptida [Features of bone marrow hematopoiesis in secondary chronic inflammation with glucosaminylmuramyl dipeptide]. Eksperimental'na ${ }^{3} \mathrm{kl}^{3} \mathrm{n}^{3} \mathrm{chna}$ medicina, 1 (70), 68-75.

Received: 03-Jun-2019

Accepted: 09-Sep-2019 